\title{
HEAVY METAL CONTAMINATION OF AMARANTHUS GROWN ALONG MAJOR HIGHWAYS IN LAGOS, NIGERIA
}

\author{
M.O. ATAYESE, A.I. EIGBADON ${ }^{2}$, K.A. OLUWA ${ }^{2}$ and J.K. ADESODUN ${ }^{1}$ \\ Department of Plant Physiology and crop Production, University of Agriculture, Abeokuta, Nigeria \\ ${ }^{1}$ Department of Botany, Lagos State University, Badagry Express way, Lagos, Nigeria \\ ${ }^{2}$ Department of Soil Science and Land Management, University of Agriculture, Abeokuta, Nigeria
}

(Received 16 April, 2009; accepted 25 July, 2009)

\begin{abstract}
Consumption of food contaminated with heavy metals is a major source of health problems for man and animals. Vegetable cropping along major highways with heavy vehicular movement has been a serious concern to food safety experts in large cities. A study was, therefore, carried out in two major highways in Lagos, Nigeria to determine the extent of lead $(\mathrm{Pb})$ and cadmium (Cd) contamination in vegetable tissues. Samples of soil and plant (Amaranthus viridis) were collected from three sites; two of which were located on major highways, and another in a rural area which served as the reference site. These samples were collected at distances of 5, 10,15 and $20 \mathrm{~m}$ from the roadside and analysed for $\mathrm{Pb}$ and $\mathrm{Cd}$. Levels of $\mathrm{Pb}$ and $\mathrm{Cd}$ in soil were found to be 47 to $151 \mathrm{mg} \mathrm{kg}^{-1}$ and 0.30 to $1.33 \mathrm{mg} \mathrm{kg}^{-1}$ (dry weight) respectively. Concentrations in leaves ranged from 68 to $152 \mathrm{mg} \mathrm{kg}^{-1} \mathrm{and}^{0.5}$ to $4.9 \mathrm{mg} \mathrm{kg}^{-1}$ (dry weight) for $\mathrm{Pb}$ and $\mathrm{Cd}$, respectively. The pattern of these heavy metals deposition, as reflected by the plant concentration factor (PCF) values, showed decrease in concentration with increase in distance from the road. Heavy metal concentrations in Amaranthus cultivated on soils characterized by heavy traffic were significantly higher $(\mathrm{P} \leq 0.05)$ than those cultivated on the reference soil. These findings in general indicated that while the levels of metals in soil were within the critical limits proposed by Kabata-Pendias and Pendias (1984), the range within the plant leaves were above the normal limit for plants suggesting that amaranthus has away of concentrating metals in their tissues and or that aerial deposition may be a major source of contamination.
\end{abstract}

Key Words: Amaranthus viridis, cadmium, lead, pollution load index

\section{RÉSUMÉ}

La consommation d'aliments contaminés par des métaux lourds est une importante source de problèmes de santé pour les homme et les animaux. La culture des légumes le long des axes routiers avec une intense circulation routière a été une préoccupation majeure pour les experts de la sécurité alimentaire dans les grandes villes. Par conséquent, une étude avait été menée dans deux grands axes routiers à Lagos, au Nigéria pour déterminer le niveau de Plomb (Pb), ainsi que le niveau de contamination des tissus végetaux au Cadmium (Cd). Les échantillons de sol et de plante (Amarante viridis) avaient été collectés sur trois sites, dont deux étaient situés sur les routes principales et un autre dans une zone rurale et ayant servi comme site de référence. Ces échantillons ont été collectés à des distances de $5 ; 10 ; 15$ et $20 \mathrm{~m}$ de la route et analysés pour le $\mathrm{Pb}$ et le $\mathrm{Cd}$. La teneur du $\mathrm{Pb}$ et du Cd dans le sol se sont avérés être respectivement de 47 à $151 \mathrm{mg} \mathrm{kg}^{-1}$ et 0,30 à $1.33 \mathrm{mg} \mathrm{kg}^{-1}$ (poids sec). Les concentrations dans les feuilles allait de 68 à $152 \mathrm{mg} \mathrm{kg}^{-1}$ et 0,5 à $4,9 \mathrm{mg} \mathrm{kg}^{-1}$ (poids sec), respectivement pour le $\mathrm{Pb}$ et le $\mathrm{Cd}$. La configuration de ces dépôts de métaux lourds, comme en indique les valeurs de facteur de concentration (PCF), représente une baisse de concentration avec l'augmentation de la distance à partir de la route. Les concentrations de métaux lourds dans les amarantes cultivées sur des sols caractérisés par un trafic intense étaient considérablement plus élevée $(\mathrm{P0}, 05)$ que celles cultivées sur le sol de référence. Ces conclusions indiquaient qu'en général, bien que les niveaux de métaux dans le sol se trouvaient dans les limites critiques proposées par Kabata-Pendias et Pendias (1984), l’intervalle dans lequel les feuilles des plantes étaient au delà de 
limite normale pour les plantes suggèrent que les amaranthes détenaient de loin des métaux concentrés dans leurs tissus et/ou que ce dépôt aérienne pourrait être une source majeure de contamination.

Mots Clés: Amarante viridis, cadmium, plomb, indice de charge de pollution

\section{INTRODUCTION}

Green amaranth or pigweed (Amaranthus viridis), which belongs to the Family Amaranthaceae is a cosmopolitan herbs. Approximately 60 species of Amaranthus are presently recognised (Wagner et al., 1999). In some parts of the world, it is classified as a weed, but in West Africa it is cultivated for its edible leaves (Stone, 1970). In Nigeria, it is a common vegetable which goes with some carbohydrate dishes. It is also a very good source of vitamins including vitamin A, B6, and $\mathrm{C}$; riboflavin, and foliate. It is also a major source of dietary minerals including calcium, iron, magnesium, phosphorus, potassium, zinc, copper, and manganese (Czerwiñski et al., 2004); yet its seeds have been shown to contain protein (Juan, 2007). Some studies have shown that amaranth seeds or oil may benefit people with hypertension and cardiovascular disease; hence regular consumption reduces blood pressure and cholesterol levels, while improving antioxidant status and some immune parameters, via its content of plant stanols and squalene (Gonor et al., 2006; Martirosyan et al., 2007).

In many cities in the developing world, lack of access to land make other lands including hazardous places such as road verges, banks of drainage channels and dumpsites converted to vegetable gardens. All setbacks along major highways are used by farmers for vegetable cultivation. Emissions from the heavy traffic on these roads contain lead $(\mathrm{Pb})$, cadmium $(\mathrm{Cd})$, zinc $(\mathrm{Zn})$, and nickel (Ni), which are present in fuel as anti-knock agents. This has also led to contamination of air and soils on which these vegetables are planted (Ikeda et al., 2000). Excessive accumulation of heavy metal in agricultural land through traffic emission may results in soil contamination and elevated heavy metal uptake by crops, and thus affect food quality and safety ((Ho and Tai, 1988; Garcia and Millan, 1998). Food chain contamination is one of the important pathways for the entry of these toxic pollutants in to the human body (Ferner, 2001; Ma et al., 2006). Cadmium in particular is an Environmental Protection Agency (EPA) regulated heavy metal that is used as anticorrosion and decorative coatings on metal alloys. Cadmium enters waterways through industrial discharges and galvanised pipe breakdown. It is a non-essential metal to living organisms and can become toxic by displacing zinc. Low exposures may result in kidney damage (IOSHIC, 1999). In addition, epidemiological studies have revealed that cadmium may be a contributing factor in some forms of cancer in humans (IARC, 1998). In large cities within the developed world, there are vast reports on the susceptibility of plants grown on the road sides to heavy metal contaminants, however few studies have actually addressed this issue in developing countries (Thornton, 1990; Singh et al., 2004; Chen et al., 2005; Liu et al., 2005; Muchuweti et al., 2006; Wilson and Pyatt, 2007). Therefore, this study determined (i) the total $\mathrm{Pb}$ and Cd contents of soils exposed to motor vehicle emissions and in vegetables grown along the selected roadsides, and (ii) effect of distance from the road on the heavy metal content of the vegetables.

\section{MATERIALS AND METHODS}

Study area. This study was conducted in southwest city of Lagos in Nigeria. The area has a bimodal rainfall pattern which peaks in June and September and is the commercial capital of Nigeria. It is characterised by the heaviest traffic on major highways along where the commercial vegetable cropping takes place. The soils in this area are from sedimentary rock formation and classified as Typic tropopsamments (FDALR, 1990). The common vegetables planted are amaranthus, celosia, letus and carrots.

Sampling procedure. Two sites situated along busy roads were selected. Specifically, the sites 
were Lagos State University-Iba road and LagosBadagry Expressway. Another site, Wasimi, a rural settlement in Ogun State was used as the reference site. It was characterised by no traffic densities. This site is sparsely populated and basically residential with no industrial activity taking place.

Samples of soil were taken at distance intervals of 5, 10, 15 and 20 meters from the roadway at selected sites. Three soil samples were taken from three points from each distance and mixed together to form a composite samples and three composite samples were prepared for each distance. Soil was sampled at 0-10 $\mathrm{cm}$ deep and transported to the research laboratory, while ensuring that there were no other sources of contamination at the site of investigation. Each soil sample was air dried, and all clods and crumbs were removed and mixed uniformly by sampling. Soils were sieved through a $2 \mathrm{~mm}$ sieve to remove coarse particles before sub-sampling for chemical analysis.

The soil samples were analysed for heavy metal contents; cadmium (Cd) and lead $(\mathrm{Pb})$. Similarly, samples of $A$. viridis were collected at same distances, measured at intervals $(5,10,15$ and 20 meters) from the roadway at selected sites. Three plant samples were taken from three points from each distance and mixed together to form a composite sample and three composite samples were prepared for each distance. The plant materials were then packed into polythene bags and taken to the laboratory for analysis.

Determination of heavy metal content of the soil. A sample of $0.5 \mathrm{~g}$ of air-dried ground soil was transferred to a $25 \mathrm{ml}$ conical flask; $5 \mathrm{ml}$ of concentration $\mathrm{H}_{2} \mathrm{SO}_{4}$ was added followed by 25 $\mathrm{ml}$ of conc. $\mathrm{HNO}_{3}$ acid, and $5 \mathrm{ml}$ of concentration $\mathrm{HCl}$. The contents of the tube were heated at $200^{\circ} \mathrm{C}$ for 1 hour in a fuming hood, and then cooled to room temperature. After cooling, $20 \mathrm{ml}$ of distilled water was added and the mixture was filtered using filter paper No.1 $(11 \mathrm{~cm})$ to complete the digestion.

Finally, the mixture was transferred to a $50 \mathrm{ml}$ volumetric flask, filled to the mark, and let to settle for at least 15 hours. The supernatant was analysed for total $\mathrm{Cd}$ and $\mathrm{Pb}$ by Atomic
Absorption Spectrophotometery (model BUCK 210VGP).

Determination of total metal content in plants. Whole plants were divided into roots, leaves, and stem. The samples were weighed to determine the fresh weight and then dried in an oven at $60^{\circ}$ $\mathrm{C}$ for 48 hours. The dry samples were crushed in a mortar and the resulting powder was packaged for analysis of the heavy metals $\mathrm{Cd}$ and $\mathrm{Pb}$. Approximately $0.5 \mathrm{~g}$ of the powder was transferred to a $25 \mathrm{ml}$ conical flask; $5 \mathrm{ml}$ of concentration $\mathrm{H}_{2} \mathrm{SO}_{4}$ was added followed by 25 $\mathrm{ml}$ of conc. $\mathrm{HNO}_{3}$ acid, and $5 \mathrm{ml}$ of concentration $\mathrm{HCl}$. The contents of the tube were heated at $200^{\circ} \mathrm{C}$ for 1 hour in a fuming hood, and then cooled to room temperature. Then, $20 \mathrm{ml}$ of distilled water was added and the mixture was filtered using filter paper No.1 $(11 \mathrm{~cm})$ to complete the digestion of organic matter.

Finally, the mixture was transferred to a $50 \mathrm{ml}$ volumetric flask, filled to the mark, and let to settle for at least 15 hours. The resultant supernatant was analysed for total $\mathrm{Cd}$ and $\mathrm{Pb}$ by Atomic Absorption Spectrophotometer.

Transfer factor of metals from soil to plant. Metal concentrations in the extracts of soils and plants were calculated on the basis of dry weight. The plant concentration factor (PCF) was calculated as follows:

$\mathrm{PCF}=\mathrm{C}_{\text {plant }} / \mathrm{C}_{\text {soil }} \ldots \ldots \ldots \ldots \ldots \ldots \ldots \ldots . . . . . \ldots$ Equation 1

where Cplant and Csoil represent the heavy metal concentration in extracts of plants and soils on dry weight basis, respectively (Cui et al., 2005).

Pollution load index. The degree of soil pollution for each metal was measured using the pollution load index (PLI) technique which depends on soil metal concentrations. The following modified equation was used to assess the PLI level in soils.

$\mathrm{PLI}=\mathrm{C}_{\mathrm{Soil}}($ Sample $) / \mathrm{C}_{\text {Refernce }} \ldots \ldots \ldots \ldots . .$. Equation 2

where $\mathrm{C}_{\text {soil }}$ (Samples) and $\mathrm{C}_{\text {reference }}$ (Reference) represent the heavy metal concentrations in the 
soils proximal to roadsides and reference soils respectively (Liu et al., 2005).

Statistical analysis. Data collected were analysed using the Statistical Package for social scientists 10 . The data were expressed in terms of discriptive statistics while the figures were presented with mean values of triplicates. The statistical significance was computed using pair samples T-test at $\mathrm{P}<0.05$

\section{RESULTS AND DISCUSSION}

Data for concentrations of metals in roadside soils are presented in Table 1. The heavy metal contents in the soils varied significantly from site to site. $\mathrm{Pb}$ content in soils ranged from 47 - 151 $\mathrm{mg} \mathrm{kg}^{-1}$, and Cd ranged from $0.3-1.33 \mathrm{mg} \mathrm{kg}^{-1} . \mathrm{Pb}$ concentrations were lower than European Commission (EC) upper limit of $300 \mathrm{mg} \mathrm{kg}^{-1}$ (EC, 1986) and was at lower concentrations than the maximum tolerable levels proposed for agricultural soils, 90 - $300 \mathrm{mg} \mathrm{kg}^{-1}$ (Kabata-Pendias and Dudka, 1984). Pb values obtained in the present study substantially exceed reported background values of $25 \mathrm{mg} \mathrm{kg}^{-1} \mathrm{~Pb}$ in soil (SEPA, 2005).

The two sites had Cd lower than or a little higher than the lower limit of the recommended 1 $-3 \mathrm{mg} \mathrm{kg}^{-1} \mathrm{EC}$ limit. However, the sources of Cd in the urban areas could be more from metal plating and lubricating oils. It could also be due to rough surfaces of the roads which increase the wearing of tyres, and run-offs from the roadsides (Hewitt and Rashed, 1988).

Variation in soil heavy metal contents with distance from the road. Heavy metal contents in roadside soils decreased with increasing distance from the road (Fig. 1). Pb concentrations were higher in Afromedia soils than soils in LASU Gate and the reference site.

Similarly, Cd concentrations decreased with increasing distance from the road but their levels

TABLE 1. Heavy metal contents in roadside soils of Lagos, Nigeria

\begin{tabular}{llll}
\hline Metal & \multicolumn{2}{l}{ Site } & \\
\cline { 2 - 4 } & Lasu gate & Afromedia & Reference site \\
\hline $\mathrm{Pb}$ (soil) & $99 \pm 7.18$ & $151 \pm 29.86$ & $47 \pm 0.75$ \\
$\mathrm{Cd}$ (soil) & $1.33 \pm 0.13$ & $1.12 \pm 0.09$ & $0.30 \pm 0.07$ \\
\hline
\end{tabular}

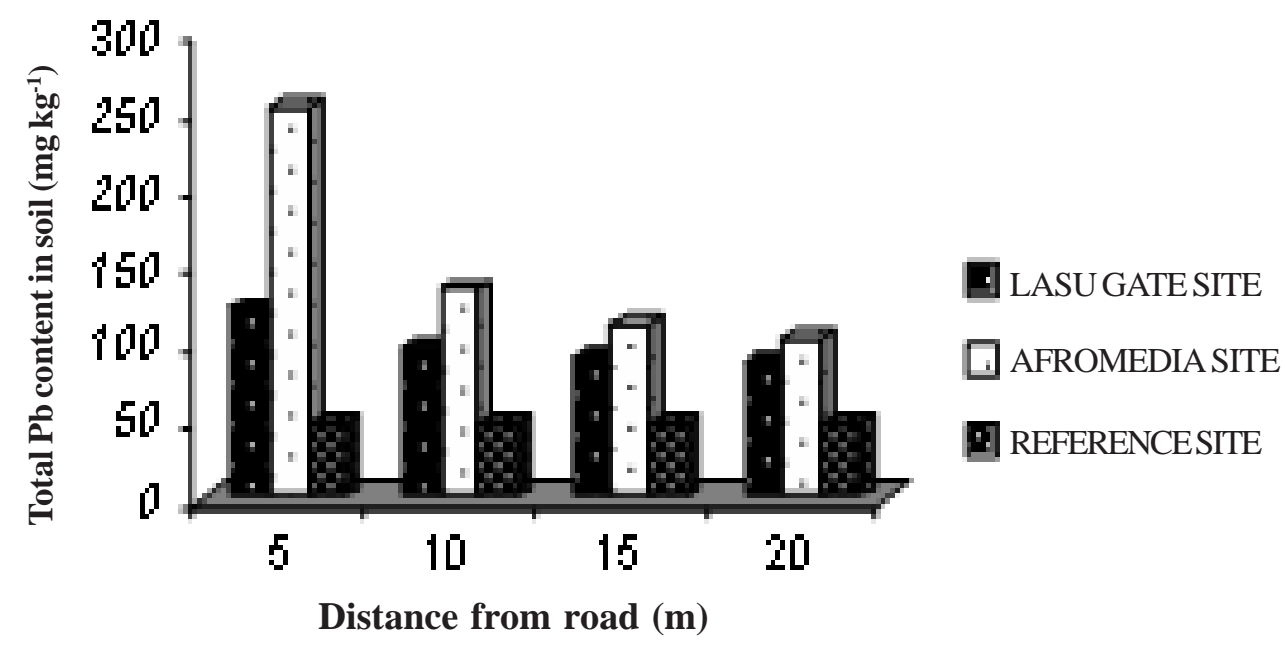

Figure 1. Total Pb content in roadside soil of Lagos, Nigeria. 
were not consistently proportional with increasing distance at LASU Gate (Fig. 2).

Pollution load index (PLI). The PLI value shows significant difference between the mean values of $5 \mathrm{~m}$ and $10 \mathrm{~m}$ at $(\mathrm{P} \leq 0.05)$ at the two locations but lower at LASU Gate than Afromedia (Tables 2 and 3). It only showed significant difference $(\mathrm{P} \leq 0.05)$ between the mean values of $\mathrm{Pb}$ at LASU Gate and Afromedia at distances of 10 to $20 \mathrm{~m}$.
The PLI value showed no significant difference $(P \leq 0.05)$ between the mean values of $\mathrm{Cd}$ at the two sampling sites at various distances.

Lead and cadmium composition in amaranthus plant. The $\mathrm{Pb}$ content in Amaranthus leaf is highest at Afromedia and lowest at the reference site (Fig. 3). Also, there is evidence of a decrease in concentration with increase in distance at each site.

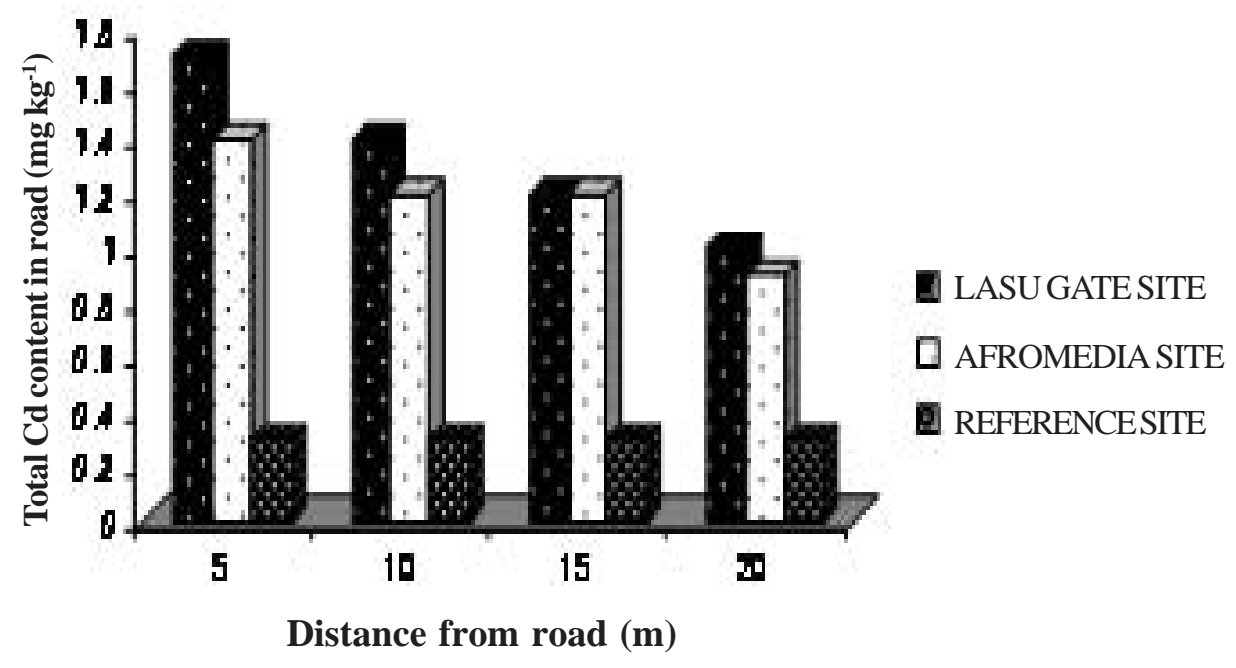

Figure 2. Total $\mathrm{Cd}$ content in roadside soil of Lagos, Nigeria

TABLE 2. Pollution Load Index (PLI) of Pb in roadside soil of Lagos, Nigeria

\begin{tabular}{lllll}
\hline Site & \multicolumn{4}{c}{ Distance from the road $(\mathrm{m})$} \\
\cline { 2 - 5 } & $5(\mathrm{~m})$ & $10(\mathrm{~m})$ & $15(\mathrm{~m})$ & $20(\mathrm{~m})$ \\
\hline Lasu gate & $2.62 \pm 0.12$ & $2.06 \pm 0.14$ & $1.89 \pm 0.13$ & $1.85 \pm 0.11$ \\
Afromedia & $5.38 \pm 0.11$ & $2.87 \pm 0.23$ & $2.38 \pm 0.35$ & $2.19 \pm 0.13$ \\
\hline
\end{tabular}

TABLE 3. Pollution Load Index for Cd in soil alongside roads in Lagos, Nigeria

\begin{tabular}{|c|c|c|c|c|}
\hline \multirow[t]{2}{*}{ Site } & \multicolumn{4}{|c|}{ Distance from the road (m) } \\
\hline & $5(m)$ & $10(\mathrm{~m})$ & $15(m)$ & $20(m)$ \\
\hline Lasu gate & $5.7 \pm 1.2$ & $4.7 \pm 1.3$ & $4.0 \pm 1.2$ & $3.3 \pm 1.6$ \\
\hline Afromedia & $4.7 \pm 1.3$ & $4.5 \pm 1.4$ & $4.1 \pm 1.4$ & $3.8 \pm 1.5$ \\
\hline
\end{tabular}




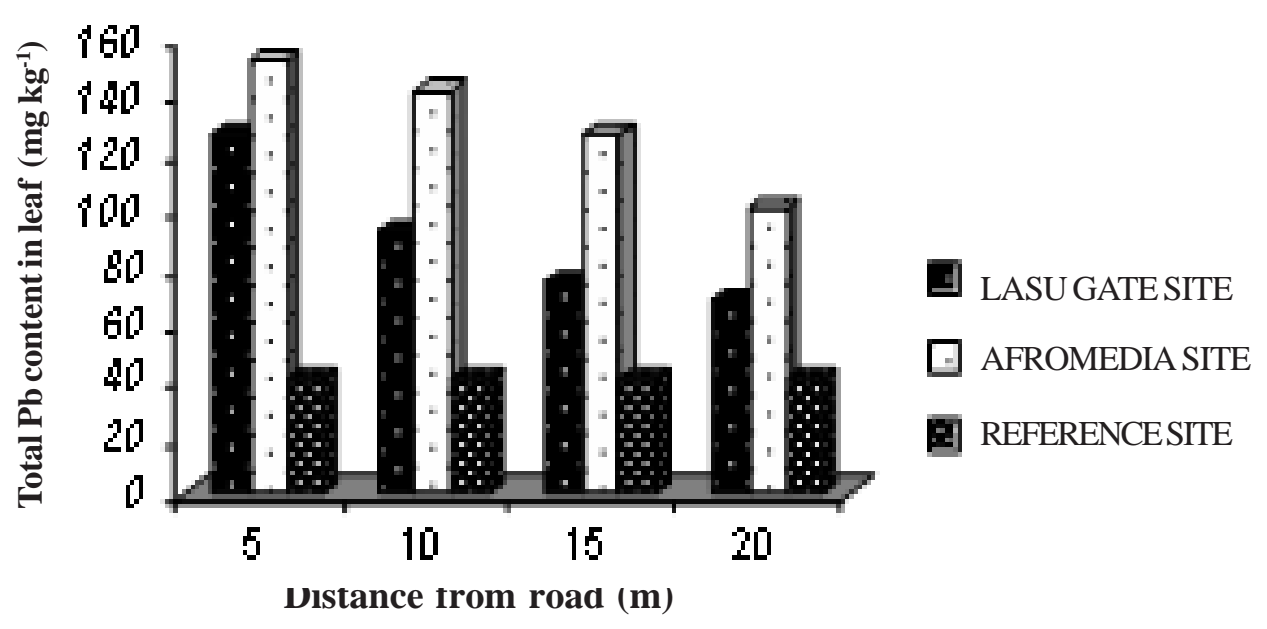

Figure 3. Total $\mathrm{Pb}$ content in Amaranthus leaves given along Lagos, Nigeria roads.

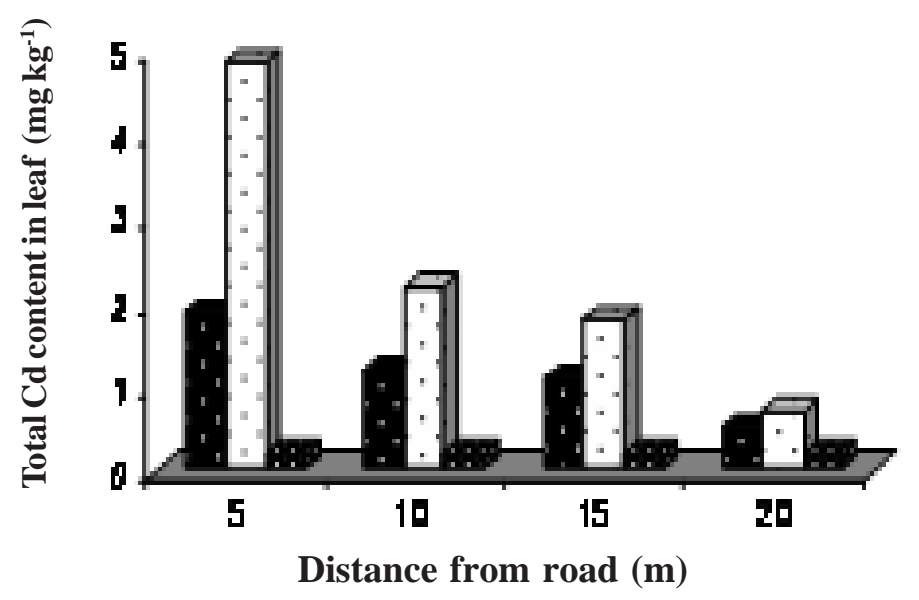

LASU GATE SITE

AFROMEDIA SITE

9 REFERENCESITE

Figure 4. Total $\mathrm{Cd}$ content in Amaranthus grown along Lagos, Nigeria roads.

The $\mathrm{Pb}$ content in the leaf decreased with increased distance in LASU Gate and Afromedia, but remained constant in the reference site.

The Cd content in the leaf is highest at Afromedia (4.9 $\mathrm{mg} \mathrm{kg}^{-1}$ ) and lowest at the reference site ( $\left.0.2 \mathrm{mg} \mathrm{kg}^{-1}\right)$ (Fig. 4). Here too was evidence of a decrease in concentration with increase in distance at each site. This result is similar to those of Rodriguez et al. (1982) who reported that accumulation of $\mathrm{Pb}$ and $\mathrm{Cd}$ above background levels takes place up to a distance of approximately $33 \mathrm{~m}$. This led them to suggest that edible crops for human or animal consumption should be restricted within strips of this width on both sides of heavily travelled roads. Motto et al. (1970) also found that most of the effects of $\mathrm{Pb}$ discharge from automobiles is confined within a zone $33 \mathrm{~m}$ wide, measured from the road edge. Ward et al. (1975), however, suggested a more conservative value of $100 \mathrm{~m}$ on either side of road edges.

$\mathrm{Pb}$ and $\mathrm{Cd}$ contents in Amaranthus stem were highest at LASU gate (131 and $4.0 \mathrm{mg} \mathrm{kg}^{-1}$ respectively) and lowest at the reference site (48 and $0.4 \mathrm{mg} \mathrm{kg}^{-1}$, respectively) (Figs. 5 and 6). Relatively uniform concentrations of Cd were found at 5, 10 and $15 \mathrm{~m}$ with values at 2.4, 2.2, and $2.1 \mathrm{mg} \mathrm{kg}^{-1}$, respectively. Figure 6 equally show 


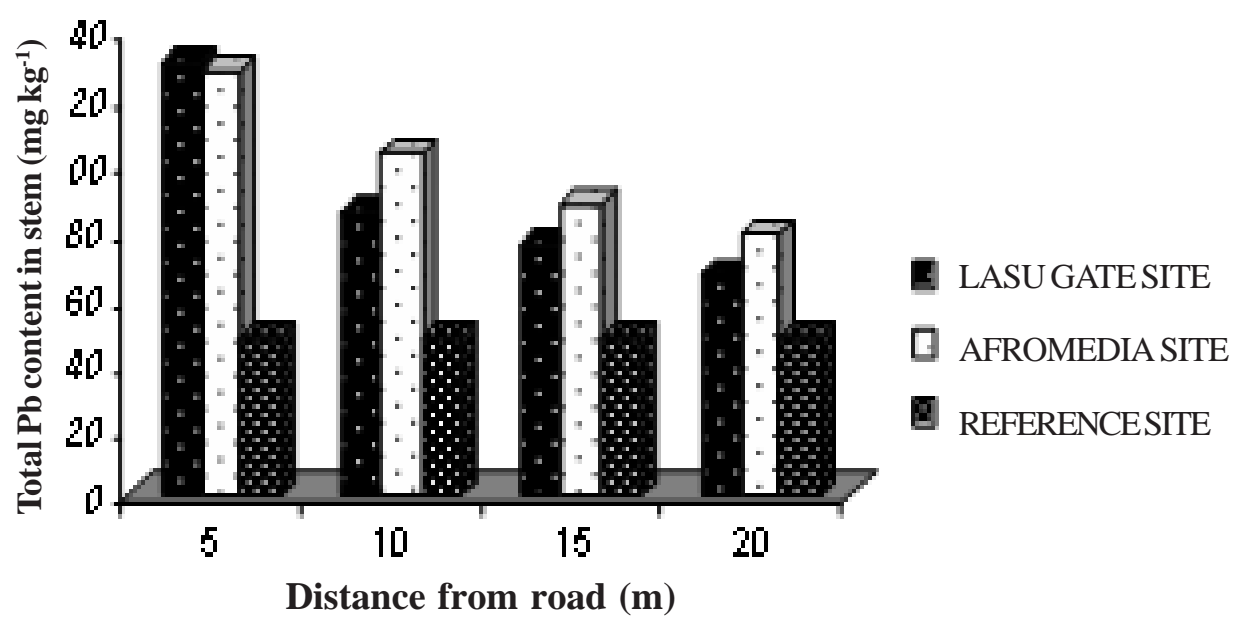

Figure 5. Total Pb content in stem of Amaranthus grown alongside roads of Lagos, Nigeria.

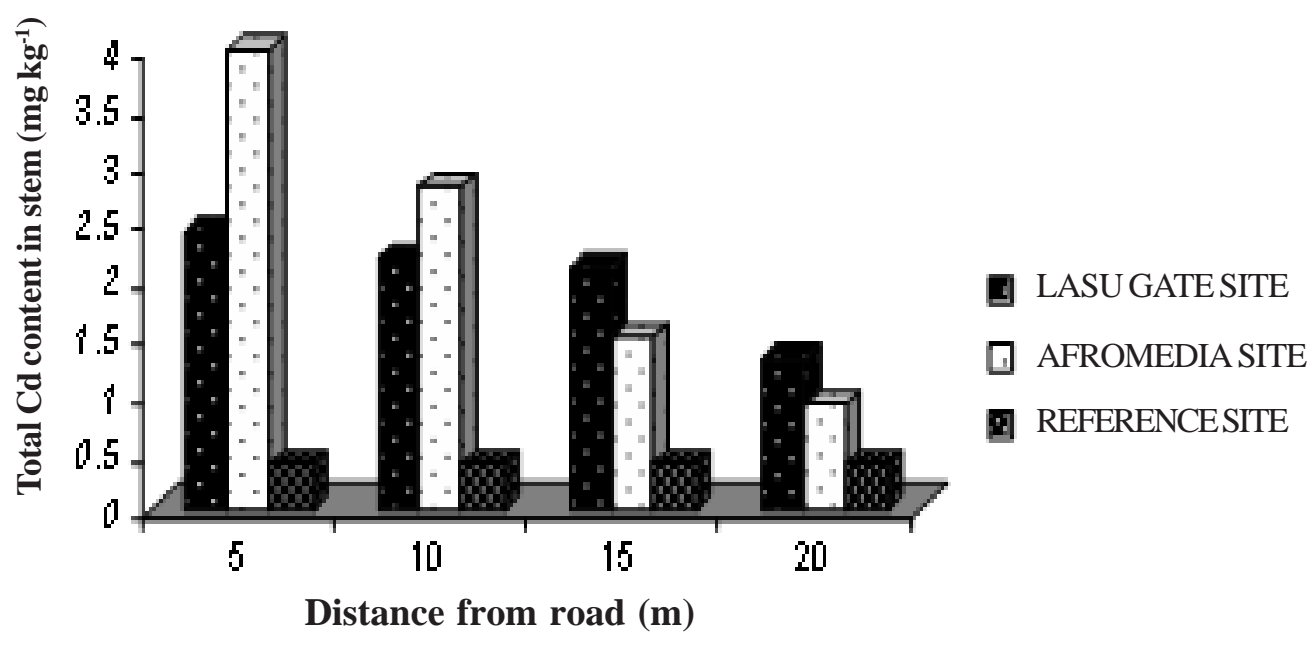

Figure 6. Total $\mathrm{Cd}$ content in stem of Amaranthus grown alongside roads of Lagos, Nigeria.

decrease in concentration with increase in distance at each site.

$\mathrm{Pb}$ and $\mathrm{Cd}$ content of the plant root followed the same pattern as in the leaves and the stem, but were considerably higher in the root tissues (Figs. 7 and 8). Root $\mathrm{Pb}$ and $\mathrm{Cd}$ contents were highest at Afromedia (369 and $6.5 \mathrm{mg} \mathrm{kg}^{-1}$, respectively) and lowest at the reference site (50 and $0.6 \mathrm{mg} \mathrm{kg}^{-1}$, respectively).

At $20 \mathrm{~m}$, the concentration of Cd was found to be equal at the two test sites but higher than the reference site (Fig. 8), and the figure similarly shows decrease in concentration with increase in distance at each.

Plant leaves are known to reflect the elements inputs for a known exposure time (Alfani et al., 2004). The highest content of Cd was found in roots of plant species from Afromedia. However, the level of Cd in this study was higher than $2 \mathrm{mg}$ $\mathrm{kg}^{-1}$ reported by Ho and Tai (1988) and Awofolu (2005) in similar studies. Normally, plant metal levels for $\mathrm{Pb}$ vary in the range of $1-12 \mathrm{mg} \mathrm{kg}^{-1}$ dry weight (Fleming and Parle, 1977). Chambers and Sidle (1991) found that plant metal levels 


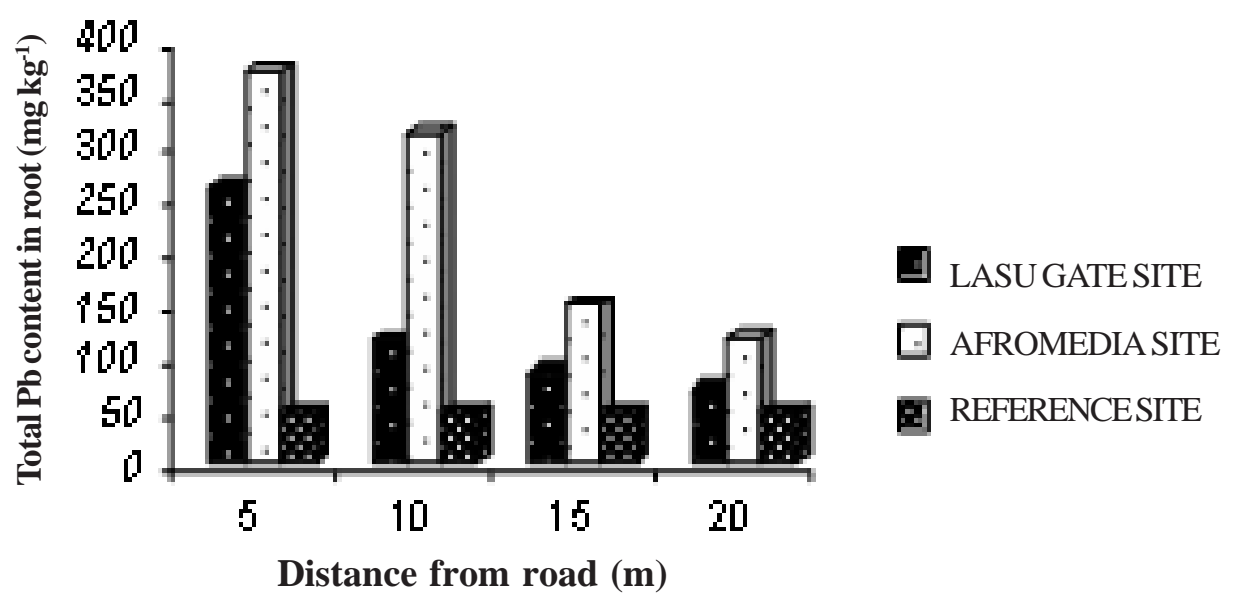

Figure 7. Total $\mathrm{Pb}$ content in root.

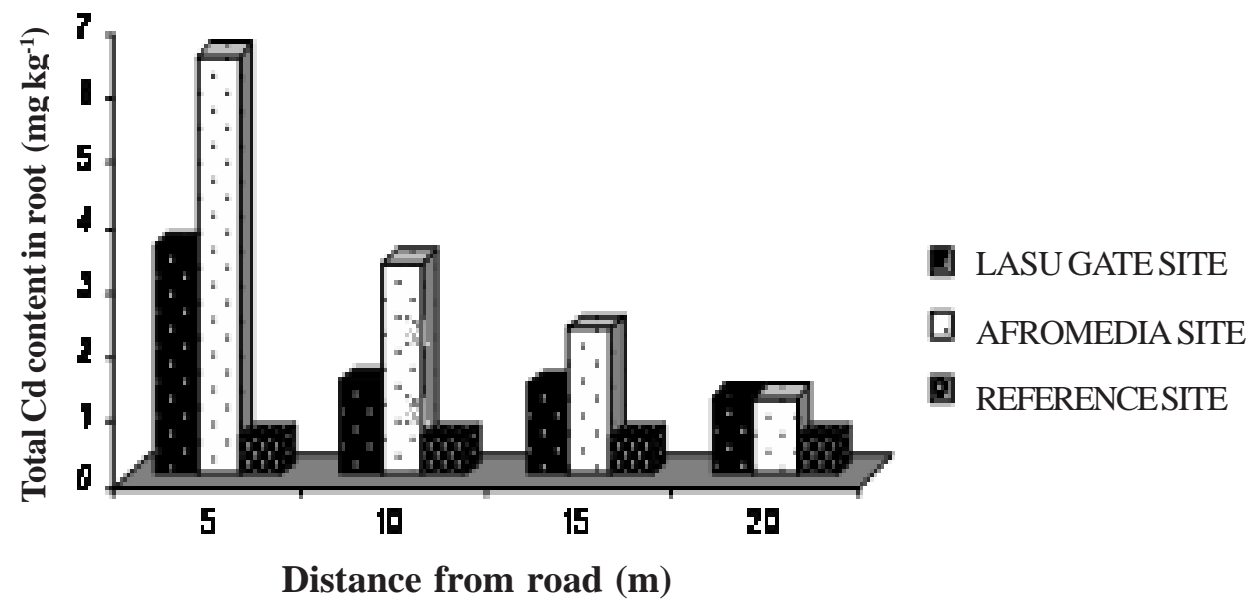

Figure 8. Total $\mathrm{Cd}$ content in root.

highly vary when related to soil metal levels. Also, according to Fleming and Parle (1977), the uptake of heavy metal varies widely depending on the plant species being studied. They also found that metal uptake was controlled by such variable as soil $\mathrm{pH}$, organic matter content and soil type. Generally, most of heavy metals are less available to plants under alkaline conditions, than under acid conditions as reported by Hess (1971). In this study, plant Cd levels were found higher than soil levels in all of the plants. This indicates that Cd uptake by plant is not restricted at these sites by $\mathrm{pH}$ or other factors. The high $\mathrm{Cd}$ content in plant appears to be due to a direct deposition and foliar absorption more than the translocation from roots to the upper part of the plants.

Transfer factor. The Plant Concentration Factor (PCF) is the summation of the mean values of the metals concentrations in the leaf, stem and the root. The $\mathrm{PCF}$ of $\mathrm{Pb}$ and $\mathrm{Cd}$, in plant samples are presented in Tables 4 and 5. There was no difference $(\mathrm{P} \leq 0.05)$ in PCF values of lead at LASU Gate and Afromedia at the different distances. It was, however low at the 20 meter distance in both locations. On the contrary, difference existed between the Cd PCF values in both locations at the various distances. Also, the value was 
TABLE 4. Plant Concentration Factor (PCF) of mean of $\mathrm{Pb}$

\begin{tabular}{lllll}
\hline Site & \multicolumn{4}{c}{ Distance from the road $(\mathrm{m})$} \\
\cline { 2 - 5 } & $5(\mathrm{~m})$ & $10(\mathrm{~m})$ & $15(\mathrm{~m})$ & $20(\mathrm{~m})$ \\
\hline Lasu gate & 4.23 & 3.49 & 3.00 & 2.54 \\
Afromedia & 4.13 & 3.25 & 2.86 & 2.57 \\
\hline
\end{tabular}

TABLE 5. Plant Concentration Factor (PCF) of mean of Cd

\begin{tabular}{lllll}
\hline Site & \multicolumn{4}{c}{ Distance from the road $(\mathrm{m})$} \\
\cline { 2 - 5 } & $5(\mathrm{~m})$ & $10(\mathrm{~m})$ & $15(\mathrm{~m})$ & $20(\mathrm{~m})$ \\
\hline Lasu gate & 5.65 & 4.80 & 3.50 & 3.01 \\
Afromedia & 11.12 & 6.92 & 4.67 & 3.11 \\
\hline
\end{tabular}

observed to be far higher in Afromedia at $5 \mathrm{~m}$ compared to LASU gate. This suggests that cadmium gets into the vegetables tissues through some other sources other than air. Cadmium and lead toxicity symptoms are likely after a long time of continuous consumption.

\section{CONCLUSION}

Roadside farming activities in the city may be intolerable at distances of up to $20 \mathrm{~m}$ from the edge of the road. When cultivation of vegetables is inevitable due to population pressure, construction of barriers between roadsides and gardens could reduce the amount of heavy metals accumulated by these crops from the emissions and other aerial sources. Allocation and monitoring of land usage within big cities could help to reduce the use of hazardous areas for agricultural activities. Regulation of vehicle emissions and the introduction of unleaded fuel are also integral part of strategic plans to maintain a generally safe environment in cities of developing countries.

\section{ACKNOWLEDGEMENTS}

The authors acknowledge the Management of the Lagos State University, Lagos, Nigeria for giving Dr Atayese, M.O. the opportunity to spend a year sabbatical leave when this work was carried out. We also thank the Department of Botany of the University for the Technical Staff and the laboratory space.

\section{REFERENCES}

Alfani, A., Maisto, G., Baldantoni, D., Anna, D. M. and De Santo, A.V. (2004). Trace metals in the soil and in Quercus ilex. Leaves at anthropic and remote sites of the campania region of Italy. Geoderma. 122: 269-279.

Awofolu, O.R. 2005. A survey of Trace metals in vegetation, soil and lower animals along some selected major and Roads in metropolitan city of Lagos. Environmental monitoring and Assessment 105: 431-447.

Chambers, J. and Sidle, R. 1991. Fate of heavy metals in an abandoned lead-zinc tailings pond: 1, Vegetation. J. Environ. Qual. 20: 745758.

Chen, Y., Wang, C. and Wang, Z. 2005. Residues and source identification of persistentorganic pollutants in farmland soils irrigated by effluents from biological treatment plants. Environment International 31:778-783.

Cui, Y.J., Zhu, Y.G., Zhai, R., Huang, Y., Qiu, Y. and Liang, J. 2005. Exposure to metal mixtures and human health impacts in a contaminated 
area in Nanning, China. Environment International. 31: 784-790.

Czerwinski, J., Bartnikowska, E., Leontowicz, H., Lange, E., Leontowicz, M., Katrich, E., Trakhtenberg, S. and Gorinstein, S. 2004. Oat (Avena sativa) and amaranth (Amaranthus hypochondriacus) meals positively affect plasma lipid profile in rats fed cholesterolcontaining diets. J Nutr Biochem. 10:622-629.

EC (European Commissio). 1986. European Commission, Office for Official publications of the European Communities, Luxembourg, Council Directive 66/278/EEC on the protection of environment, and in particular of soil, when sewage sludge is used in agriculture.

FDALR (Federal Department of Agricultural Land resources), 1990. Soil Map of Nigeria Project: Soil of Ogun-state. pp. 63-65; 148.

Ferner, D. J. 2001. Toxicity heavy metals. eMed. Jor. 2 (5): 1.

Fleming, G. and Parle, P. 1977. Heavy metals in soils, herbage and vegetables from an industrialized area west of Dublin city. Irish J. Agric. Res. 16: 35-48.

Garcia, R. and Millan, E. 1998. Assessment of Cd, $\mathrm{Pb}$ and $\mathrm{Zn}$ contamination in roadside soils and grasses from Gipuzkoa (Spain). Chemosphere 37:1615-1625.

Gonor, K. V., Pogozheva, A. V., Derbeneva, S. A., Mal'tsev, G., Trushina, E. N and Mustafina, O. K. 2006. The influence of a diet with including amaranth oil on antioxidant and immune status in patients with ischemic heart disease and hyperlipoproteidemia. Vopr Pitan.75 (6): 30-33.

Hess, P. 1971. A textbook of soil chemical analysis. London. Murray.

Hewitt, C.N. and Rashed, M. 1988. Proc. Int. Conf. Chemicals in the Environment.

Ho, I. B. and Tai, K. M. 1988. Elevated levels of lead and other. Metals in Roadside Soil and Grass and their use to monitor Aerial metal Depositions in Hong Kong. Environ Pollut. 49: 37-51.

IARC 1998. International Agency for Research on Cancer. Cadmium and certain $\mathrm{Cd}$ compounds. In: IARC monographs on the evaluation of the carcinogenic risk of chemicals nto humans. Chemicals, Industrial processes and industries associated with cancer in humans. IARC monographs. Vol. 129. International Conference on Food Security of Urban and Peri-urban Systems in developing countries. November 15-18, 2000. Vienna, Austria.

Ikeda, M., Zhang, Z.W., Shimbo, S., Watanabe, T., Nakatsuka, H., Moon, C.S., MatsudaInoguchi, N. and Higashikawa, K. 2000. Urban population exposure to lead and cadmium in east and south-east Asia. Science of the Total Environment. 249: 373-384.

IOSHIC. 1999. International Occupational Safety and Health Information Centre. Metals. In Basics of Chemical Safety, Chapter 7, 1999 Sep. Geneva: International Labour Organization.

Juan, M. S. 2007. Electrophoretic characterization of Amaranthus L. seed proteins and its systemic implication. Botanical Journal of the Linnean Society. 155: 57-63.

Kabata-Pendias, A. and Pendias, H. 1984. Trace elements in Soils and Plants. CRC Press, Boca Raton, USA.

Liu, W. H., Zhao, J. Z., Ouyang, Z. Y., Soderlund, L., Liu, G. H., 2005. Impacts of sewage irrigation on heavy metals distribution and contamination in Beijing, China. Environment International 31: 805-812.

Ma, H. W., Hung, M. L., Chen, P. C., 2006. A systemic health risk assessment for the chromium cycle in Taiwan. Environment International. 10:1016

Martirosyan, D. M., Miroshnichenko, L. A., Kulakova, S. N., Pogojeva, A. V., and Zoloedov, V. I. 2007. Amaranth oil application for coronary heart disease and hypertension. Lipids Health Dis. 6:1.

Motto, H. L., Daines, R. H., Chilko, D. M. and Motto, C. K. 1970. Lead in soils and plants: Its relationship to traffic volumes and proximity to highways. Environ. Sci. Technol. 4: 231-237.

Muchuweti, M., Birkett, J.W., Chinyanga, E., Zvauya, R., Scrimshaw, M.D. and Lester, J.N. 2006. Heavy metal content of vegetables irrigated with mixture of wastewater and sewage sludge in Zimbabwe: implications for 
human health. Agriculture. Ecosystem and Environment 112:41-48.

Rodriguez-Flores, M. and Rodriguez-Castellon, E. 1982. Lead and Cadmium levels in soil and plants near highways and their correlation with traffic density. Environmental Pollution. series B (4): 281-290.

SEPA, 2005. The limit of pollutant in food. State Environmental Protection Administration, China. GB 2762-2005.

Singh, K.P., Mohan, D., Sinha, S. and Dalwani, R. 2004. Impact assessment of treated/untreated wastewater toxicants discharged by sewage treatment plants on health, agricultural, and environmental quality in the wastewater disposal area. Chemosphere 55:227-255.

Stone, B. C. 1970. The flora of Guam. Micronesica. 6:1-659.
Thornton, I. 1990. Metal Contamination of Soils in Urban Areas. In Bullock, P. and Gregory, P. J. (Ed.).

Wagner, W. L., Herbst, D. R. and Sohmer, S. H. 1999. Manual of the flowering plants of Hawaii. Revised edition. Bernice, P. Bishop Museum special publication. University of Hawaii Press/Bishop Museum Press, Honolulu. 1919 pp. (two volumes).

Ward, N. I., Reeves, R. D. and Brooks, R. R. 1975. Lead in soil and vegetation along a New Zealand State highway with low traffic volume. Environ. Pollut. 9: 243-251.

Wilson, B. and Pyatt, F.B. 2007. Heavy metal dispersion, persistence, and bioaccumulation around an ancient copper mine situated in Anglesey. UK. Ecotoxicology and Environmental Safety 66, 224-231. 